\title{
THE CONCEPT "STUDENT" IN THE RUSSIAN AND GERMAN LINGUOCULTURES
}

Dilyara Marsovna Sadykova

Kazan Federal University, Kazan, Russia.

Tatiana Yakovlevna Zaglyadkina

Kazan Federal University, Kazan, Russia.

Olga Valerevna Akimova

Kazan Federal University, Kazan, Russia.

Alfiya Nailevna Zaripova Kazan Federal University, Kazan, Russia.

E-mail: lelpam@mail.ru

Recepción: 05/08/2019 Aceptación: 09/09/2019 Publicación: 23/10/2019

Gitación sugerida:

Sadykova, D.M., Zaglyadkina, T.Y., Akimova, O.V. y Zaripova, A.N. (2019). The concept "student" in the Russian and German linguocultures. 3C TIC. Cuadernos de desarrollo aplicados a las TIC. Edición Especial, Octubre 2019, 72-89. doi: https://doi. org/10.17993/3ctic.2019.83-2.72-89

\section{Suggested citation:}

Sadykova, D.M., Zaglyadkina, T.Y., Akimova, O.V. \& Zaripova, A.N. (2019). The concept "student" in the Russian and German linguocultures. 3C TIC. Cuadernos de desarrollo aplicados a las TIC. Special Issue, October 2019, 72-89. doi: https://doi. org/10.17993/3ctic.2019.83-2.72-89 


\section{ABSTRACT}

The research rationale for the problem under study is in the profound changes which happened recently in Russia and affected the educational sphere and influenced the development of the Russian language, in particular the activisation of the metaphorical statements use processes in academic discourse. The purpose of the article lies in consideration of metaphorical diffuseness of the academic concept "Student" in the Russian and German linguocultures. The leading method in this research is the analysis of metaphorical diffuseness of the above-mentioned concept on the basis of the analysis of lexical units of full text databases of the German and Russian media, fiction, and Internet communication. As a result of the performed analysis it was revealed that in language picture of the world the appeal to the concept "Student" is quite popular. The figurative component of the concept is clearly expressed. But for language consciousness the most relevant is the German concept as its extra-zone includes some associations which were not found in the Russian language picture of the world.

The material of the article can be useful in Lexicology of the German and Russian languages, in training courses on cross-cultural communication, regional geography and linguistic and cultural studies of Russia and Germany, in practice of the Russian and German academic communication.

\section{KEYWORDS}

Language, Linguistics, Student, Concept, Higher education, Analysis, Lexeme. 


\section{INTRODUCTION}

\subsection{THE RELEVANCE OF THE PROBLEM}

At present in the era of globalization we are all witnesses and participants of the process of interpenetration and interaction of different cultures, which is naturally reflected in the language changes (Kalegina, Takhtarova, \& Zaglyadkina, 2015). The profound changes which occurred recently in Russia affected all spheres of social, political and economic development and engaged the educational sphere as well. Public changes of this sort influence development of language, in particular they intensify processes of the use of metaphorical expressions in the academic discourse.

The metaphor is one of the most widespread ways of lexical and also phraseological replenishment of language stock (Golshtejn \& Kerimov, 2008). The intensity of functioning of any concept is expressed in the sum of its two indicators - the nominative density and metaphorical diffuseness (Sly`shkin, 2004). Metaphorical expressions reflect the ideas of modern Russian reality and also form this representation (Shhurina, 2008). According to Lakoff and Johnson the metaphor penetrates all our everyday life and are intergrated not only in language, but also in thought and action (Lakoff \& Dzhonson, 1990). In the research of metaphorical expressions, the attention focuses, first of all, on how this phenomenon is used in the course of human communication (Kubryakova, 2004). Meanwhile, each language has inner peculiarities which challenge its learners along with its native speakers (Babenko, 2015).

\subsection{RESEARCH HYPOTHESIS}

In Russian and German linguocultures there are academic conceptual spheres which are manifested in the language system, in the associative and verbal network and in the communicative process, have national specific features and are amenable to a comparative linguistic research. The concept entering the academic sphere of concepts is the concept "Student". 


\section{METHODS}

\subsection{RESEARCH PROBLEMS}

In the research the following problems were being solved: 1) the analysis of metaphorical diffuseness of the concept "Student" on the basis of consideration of lexical units in full text databases of the German and Russian media, fiction, Internet communication; 2) the determination of similarities and differences in the concept "Student" manifestation in the German and Russian the linguocultures; 3) the analysis of the obtained results.

\subsection{THEORETICAL AND EMPIRICAL METHODS}

The conducted analysis is based on the principles of linguoculturological approach. The following methods were used:

- Theoretical - the analysis of the concept "Student" metaphorical diffuseness examples collected from various sources, analysis and generalisation of the conceptual description experience, synthesis;

- Empirical - comparison of the lexical units having metaphorical potential in the German and Russian the linguocultures and their interpretation.

\subsection{BASE OF THE RESEARCH}

The full text databases of the German and Russian media, Internet communication and fiction were research material. The text fragments which contain the metaphorical expressions based on the academic concept "Student" became the units of the research. 


\section{RESULTS AND DISCUSSION}

\subsection{METAPHORICAL DIFFUSENESS OF THE CONCEPT "STUDENT" IN THE RUSSIAN LINGUOCULTURE}

1. The concept "Student" found its embodiment in the metaphorical expression вечный студент. On the one hand the students who study many years in a higher education institution, but owing to their laziness cannot possibly finish their study are called this way (3)-(4). And on the other hand it is people who have insuperable desire to study, finishing one educational institution, they come to another, constantly craving new goals achievement (1)-(2).

The concept "Student" extrazone includes the following associations:

• вечный студент $\rightarrow$ thirst for knowledge:

(1) - Натали не только знаменитая не по годам актриса, но и... вечный студент. Не в том смысле, что не может сдать экзамены и перейти на другой курс. Наоборот, девушка обуреваема жаждой знаний. Гарварда ей не хватило, и недавно она поступила в Иерусалимский университет (Komsomolskaya Pravda). Я вечный студент и мне не стыдно. Я давно понял, что учиться намного интереснее, чем ходить на работу (https:// riamo.ru/article/263758).

(2) - Наконец в коридоре на него навалился, как медведь, Павел Иванович Мамаев, «вечный студент», уже не очень молодой, грузный, успевший побывать и в Юрьевском и в Варшавском университетах (Pavel Nilin. "Interestnaya zhizn"). 
• вечный студент $\rightarrow$ poor performance:

(3) - Один из экзаменов бедолаге пришлось сдавать аж с восьмого захода. Когда он, набив шпорами карманы, в очередной раз отправился на экзекуцию в альма-матер, зловредный препод заставил его вытряхнуть их на стол. Оставив «вечного студента» наедине с чистым листом бумаги, вышел из аудитории (Trud).

(4) - В конце концов «вечный студент» получил-таки диплом заочника пединститута по специальности русский язык и литература (Trud).

The concept "Student" extrazone extends due to the formation of new bonds in it. So, the association "thirst for knowledge" is connected with the association "age" that is evident from the examples (1) and (2).

• вечный студент $\rightarrow$ life expectancy:

(5) - Если не загружать мозг работой, старческое слабоумие обеспечено. Поэтому долгожитель - это вечный студент, он обречен постоянно воспринимать и перерабатывать новую информацию (Trud).

It is necessary to train the brain to process information constantly not to become a senile person in old age. It is proved that people of brainwork die of strokes less often. So the person caring for his health has to turn into "вечный (lifelong) студент".

2. Also certain appearance is a characteristic of the student that is reflected in the language picture of the world. A large number of examples in the Russian linguoculture is associated with the metaphorical expression "студенческий вид”: 
(6) - Почему-то в левом верхнем углу зала публика сидела довольно плотно: слева парочка хрустела и жевала, справа допивали пиво, а сзади расположилась большая компания студенческого вида, тоже с пакетами и с банками, в веселом, приподнятом настроении. (N. Ryazantseva. "Kultpohod v kino").

(7) - Помню, тогда этот скромно одетый, студенческого вида парень, высокий, худой, с бетховенской шевелюрой, принес Виталию Ивановичу какой-то свой пейзаж (Muslim Magomayev. "Lyubov moya melodiya").

The metaphorical expression “студенческий вид” is implemented in several associations: age, appearance, behavior. In terms of appearance young people can be divided into two groups: either those who give little attention to the appearance, or those who are very concerned about the latest fashion. In their company, they often do not pay attention to conventions of society and live in the student's world.

\subsection{METAPHORICAL DIFFUSENESS OF THE CONCEPT "STUDENT" IN THE GERMAN LINGUOCULTURE}

1. The concept "Student" in the German linguoculture has more expanded metaphorical diffuseness. The metaphorical expression "ein ewiger Student" spread over the following associations expanding the concept borders. It is necessary to emphasize the following:

- ein ewiger Student $\rightarrow$ poor performance:

(8) - Swen Ritter war ein ewiger Student, der es einfach nicht schaffte, sein Studium der Wirtschaftsinformatik an der TU Ilmenau abzuschließen (Internet site SpeedProject).

(9) - Schon in Venedig spielte man auf verschiedene soziale Schichten an, die man alle ansprechen wollte. Die komischen Figuren dürfen reichlich Subversives von sich geben. Es gibt immer einen Hauptkomiker, bei uns ein ewiger Student. Der nie sein Diplom macht, weil er lieber säuft als studiert (Welt online). 
Considering that the German educational system does not provide accurate time frames for the graduation from a higher education institution, it is poor performance that does not allow the German students to finish studies in an educational institution.

- ein ewiger Student $\rightarrow$ thirst for knowledge:

(10)-Der Ex-Creed und jetzt Alter Bridge Gitarrist Mark Tremonti gab dem US Magazin «Guitan ein Interview, dass speziell für Gitarrenfreaks sehr interessant sein dürfte. Der Mann am Schlagbrett erzählt von seiner Technik, dem Klang und das er ewiger Student seiner eigenen Gitarre geworden ist (Welt online).

(11) - Der vielseitigste Musiker unserer Zeit feierte im Funi seinen sechzigsten Geburtstag - David Geringas. Andere Menschen denken in dem Alter an den Ruhestand, doch der Ausnahme-Cellist sagt von sich: "Ich bin ein ewiger Student. Ich habe immer das Gefühl, dass etwas beginnt». So ist er ständig auf der Suche nach neuen Eindrücken, Aufgaben und Herausforderungen (Internet site Nordkultur.de.).

- ein ewiger Student $\rightarrow$ bashfulness:

(12) - Ich bin Dian Keto, 27 Jahre, komme aus dem kühlen Norden. Bin hier Student und ich sag euch, dass ist' ne echt geile Zeit. Doch leider bin ich nächstes Jahr fertig und muss aufgrund der Arbeitssituation aus dem schönen meerumschlungenen Bundesland weg. Ich möchte nicht, dass ihr denkt ich wär ein ewiger Student aufgrund meines fortgeschrittenen Alters. War vorher 4 Jahre Soldat (Stuttgarter Nachrichten online).

While, for example, in France or in England and also in Russia students graduate from a higher educational institution at 22-23 and begin to work, in Germany it happens approximately at 27-28. It is possible to notice that this fact is reflected in the German linguoculture where the metaphorical expression "ein ewiger Student" has a little negative shade of meaning. In example (12) it is possible to see that the young man feels uncomfortable that he leaves the walls of the university at 27.

- ein ewiger Student $\rightarrow$ traits of character: 
(13) - Er sieht aus und wirkt wie ein ewiger Student, sehr sympathish und immer freundlich (Welt online).

(14) - Der Mitbewohner ist sehr ein ruhiger Mensch, man sieht und hört ihn kaum, ein sog. alter verkrachter ewiger Student... (Welt online).

In the German linguoculture there has been created a certain image of "ein ewiger (lifelong) Student" which is justified in language by a large number of adjectives with an evaluating component as, for example, in (13) - (16):

(15) - Philippe ist schüchtern, weltfremd, verträumt. Ein ewiger Student, der wiewohl gut einiges über dreißig Fahre als noch immer an einer verschrobenen Dissertation über den Weltraumpionier Ziolkowski werkelt und noch immer bei seiner Mutter wohnt (Интернет - сайт http://www.cineman.ch/movie/2004).

(16) - Er ist ein ewiger Student, gut organisiert, dem allerdings die Lebenserfahrung fehlt (Welt online).

The image of "ein ewiger Student" is characterised by such adjectives as nice, friendly, quiet, timid, fanciful, well organized. Comparing these two metaphorical expressions in the two linguocultures, it should be noted that the number of the adjectives carrying any assessment in the Russian linguoculture is much fewer. It is possible to note the following adjectives: не молодой, грузный, скромно одетый. In the German linguoculture the traits of character of "ein ewiger Student" are more evaluated, and in the Russian - age data.

- ein ewiger Student $\rightarrow$ money

Concerning difficult financial circumstances of the students in the German linguoculture there are many jokes as, for example, in (17):

(17) - Ein ewiger Student fragt den anderen: «Sag mal, wie machst du das eigentlich, wovon lebst du?» - «Ich schreibe!» - "Oh, interessant, und was schreibst du?» fragt der erste. "Briefe, nach Hause, dass ich Geld brauche!» (Internet site GesundheitPro.de.). 
The "ein ewiger" students characterised not only by difficult financial circumstances, but also by aspiration to improve their financial position and also by ingenuity in earning money. They try to solve a financial problem together. It is seen in examples (18) and (19).

(18) - Van Wilder, ewiger Student und cooler Campuskцnig von Coolidge College hat ein Problem, als ihm sein Vater den Scheck streicht. Der wilde Wilder macht kurzerhand sein Hobby zum Beruf und organisiert Parties gegen Geld. «Nimm das Leben nicht so ernst», lautet seine Devise (Stuttgarter Nachrichten online).

(19) - Ich war ein sogenannter ewiger Student. Zusammen mit Freunden habe ich Kabarett gemacht und hatte eine Theatergruppe, um an Geld zu kommen (Jaap van Leeuwen. Portrait: Paul Dijkstra aus Utrecht - Wie ein Ideal gebrauchsfähig wird).

The examples of the same kind were not found in the Russian linguoculture.

- ein ewiger Student $\rightarrow$ appearance

(20) - Er wirkt wie ein ewiger Student. Nickelbrille, zerknittertes Leinensakko, Jeans, bequeme Straßentreter (Berliner Kurier).

(21) - Daniel Bielenstein ist rein äußerlich der Typ «ewiger Student» oder Referendar. Der Bartträger hat listig-lüstige braune Augen hinter einer Hornbrille. Das schüttere Haar ist intellektuellenmäßig zauselig unfriesiert. Zum braunen Allwetterschuh trägt er in diesen Schmuddeltagen eine beige Cordhose, darüber ein dunkelblaues Hemd zum anthrazitfarbenen Fackett - Modepäpste wie Armani und Co. wären entsetzt (Welt online).

The "ein ewiger Student" is characterised by negligence in clothes. It is comfort that is in the first place, and only then fashion comes. In the Russian linguoculture students either adhere to fashion, or do not pay any attention to it. 
2. The concept is the subject of continuous dynamic development which is influenced by the environment in which it interacts with other concepts. One association which is lacunary for the Russian culture is characteristic of the German linguoculture. The concept "Student" is connected with the concept "Car". Similar examples were not found in the Russian culture.

(22) - Das neue KA-Sondermodell «Student» soll ab sofort mit einem Listenpreis von rund 8000 Euro angeboten werden. (Süddeutsche Zeitung).

(23) - Schnell haben die Kölner aus dem Kleinwagen KA das Sondermodell «Student» gestrickt. (Welt online).

3. The concept "Student" served as a basis for metaphorical meaning of Studentenfutter (Futter - a forage (for the cattle), fodder; in colloquial language - food). In the German linguoculture Studentenfutter is associated with several options of this metaphorical expression use.

- Studentenfutter $\rightarrow$ food:

(24) - Studentenfutter ist ein idealer Pausensnack für Schule, Sport und Büro. Biologische Nüsse und Trockenfrüchte werden gemäß EU-Bio-Verordnung nicht mit chemischen oder synthetischen Mitteln behandelt. (Интернет-сайт naturkost.com).

Usually packets of nuts with raisins mixed with various dried fruits are called Studentenfutter. They are in great demand among school and university students. Most likely, the popularity of this product is caused, first of all, by its low price and high caloric content.

- Studentenfutter - cheap and quickly cooked food:

(25) - Keinen Plan, was Ihr essen sollt? Mensa zu?' Geld (fast) alle? In Cat's ultimativem Studentenkochbuch findet Ihr Studentenfutter pur: von der Vorspeise über Salate, Hauptgerichte, Desserts sowie Partyrezepte und vieles mehr - doch vor allem schnell, einfach und dem chronischen Geldmangel studentischer Portemonnaies angemessen. (Internet site Geizkragen). 
(26) - Dieses Gericht habe ich noch in Deutschland zubereitet, aus Zeitmangel habe ich es immer nicht aufgeladen. Da ich nun keine Studentin mehr bin, wird meine StudentenfutterSerie nächste Woche mit dem 6. Rezept enden. (Internet site Yahoo 360º).

As students always lack for money and time, it is extremely important for them that the process of cooking should be quick and cheap.

- Studentenfutter $\rightarrow$ finance

In this context Studentenfutter means, most likely, one of type of monetary investments into study,

In this context of Studentenfutter means, most likely, one of types of the monetary investments into study offered by local division of financial institution.

(27) - Studieren ohne Geldsorgen? Unser Studentenfutter $\times$ macht' $\boldsymbol{s}$ möglich! Mit unserem Studentenfutter $\times$ sichern Sie sich auf einen Schlag viele Vorteile, um sich voll und ganz auf Ihr Studium konzentrieren zu können. Sehen Sie selbst und vereinbaren Sie gleich einen Termin mit uns, denn wir garantieren mehr Studienerfolg durch mehr finanzielle Beweglichkeit! (Advertisement from Sparkasse Suedholstein).

4. It should be also noted the enrichment of the concept "Student" extra-zone due to the meaning transfer of the word functioning in the language several centuries ago to the modern linguoculture. Since the time of F. Schiller in the German language picture of the world the expression "Brotstudenten" is common (Brot - bread).

(28) - Ich genieße es, mit einem Dutzend Studenten in der Uni zu sitzen, der Professorin zu lauschen und angeregte Debatte zu führen. Ich mag mittlerweile sogar klassische Literatur und Klaviermusik. Ich bin kein Brotstudent, wie Schiller diejenigen nannte, die nur für ein «Amt» lernen und nicht mit den Wissenschaften «den Geist nur als Geist vergnügen» (Meine Welt im Ranzen. http://jan.twoday.net). 
(29) - Von unbeliebten Fammerprofessoren, Brotstudenten und philosophischen Köpfen: über das ewige Scheitern der Hochschule ( Süddeutsche Zeitung).

Recently expression of "Brotstudenten" became especially relevant in the light of the last transformations in the educational sphere in Europe. Still the debate on the Bologna program which entered uniform educational standards across the whole Europe continues. According to many the Bologna system turns all who begin their studies into the so-called Brotstudenten as they can be content only with the bachelor degree focused on a profession without research activities, merely learning what is given. But how in a year, having received the master's degree, they will be able to become those "philosophische Köpfe", nobody knows.

\section{SUMMARY}

A huge number of works is devoted to different researches of concepts and approaches to concept study are various. The concept is one of the most variously interpreted terms. In domestic linguistic researches the conceptual and culturological trends are of importance and have interdistsiplinarny character. In this regard it is necessary to consider the following authors' theories in concept study: Yu.S. Stepanov, A. Vezhbitskaya, N.D. Arutyunova, Yu.D. Apresyan, V.I. Karasik, G.G. Slyshkin, etc.

The analysis of the concept "Student" metaphorical diffuseness showed that the appeal to it is quite relevant both in the Russian and German linguocultures. The figurative component is most brightly expressed in the concept. For language consciousness the most relevant is the German concept as its extrazone includes such associations as food, money which were not found in the Russian language picture of the world. 
The academic concept "Student" considered by the authors had not been analysed earlier. The scientific novelty of this research lies in the analysis of metaphorical diffuseness of the given concept and obtaining the corresponding results allow us to summarize the following.

\section{CONCLUSIONS}

The student is an integral part of the educational process. Education, in turn, is one of the most important functions of culture as it provides its preservation and development (Bessarabova, 2007). In the context of the general paradigm of education, according to scientists of many countries, "education is a part of culture" (Bruner, 1996). And as the concept represents "cultural formation of the mental nature" with conceptual, figurative and valuable components (Karasik, 2002), we can tell that in a language picture of the world there was the next image of the "Student": The student in the Russian linguoculture is a slight young man who is not caring for the appearance, or on the contrary, accurately following fashion trends. This is a person of cheerful nature and high spirits. The student in the German linguoculture is a young man of 24-27, of normal constitution, often wearing spectacles, with a small beard, characterised by negligence in clothes, is unpretentious in food where, for whom simplicity and small price are the most important for it. The student is rather poor, but he aspires to earn money.

\section{ACKNOWLEDGEMENTS}

The work is performed according to the Russian Government Program of Competitive Growth of Kazan Federal University. 


\section{REFERENCES}

Kalegina, T.E, Takhtarova, S.S, \& Zaglyadkina, T.Y. (2015). Denglish and Franglais in the framework of the modern European linguistic landscape. Journal of Language and Literature, 6(3), 195-198.

Golshtejn, E.A., \& Kerimov, R. D. (2008). Konczeptual`ny`e metafory` v idiostile J.Rau. Lingvistika. Germenevtika. Konczeptologiya. Kemerovo: Kemerovskij poligraficheskij kombinat, 700 s., s.211

Sly`shkin, G.G. (2004). Lingvokul`turny`e konczepty`i metakonczepty`. Volgograd, Peremena, 340 s., s. 53

Shhurina, Yu. V. (2008). Komicheskaya metafora v sovremennom rossijskom media-diskurse. Lingvistika. Germenevtika. Konczeptologiya. Kemerovo: Kemerovskij poligraficheskij kombinat, 700 s., s.247

Lakoff, D., \& Dzhonson, M. (1990). Metafory`, kotory`mi my`zhivem.// Teoriya metafory`: Sb. statej/Pod redakcziej N.D. Arutyunovoj.-Progress, 387-416.

Kubryakova, E. S. (2004). Yazy`k i znanie. M:, Yazy`ki slavyanskoj kul`tury`.

Babenko, O. V. (2015). Language as a basic feature of ethnos uniting within the conditions of modern challenges, 6, 168-170. Retrieved from https:// www.researchgate.net/publication/298696969_Language_as_a_basic_ feature_of_ethnos_uniting_within_the_conditions_of_modern_challenges

Bessarabova, I.S. (2007). Polikul`turny j podkhod kak tendencziya razvitiya sovremennogo obrazovaniya. Menyayushhayasya kommunikacziya v menyayushhemsya mire: sb. statej / otv. red. G.G. Sly`shkin. Volgograd: FGOU VPO «Volgogradskaya akademiya gosudarstvennoj sluzhby»». Volgograd: Izd-vo FGOU VPO VAGSb s.132 
Bruner, J. S. (1996). The culture of Education. Cambridge, Mass.: Harvard University Press.

Karasik, V. I. (2002). Yazy 'kovoj krug: lichnost', konczepty`. Diskurs. Volgograd, Peremena. 
Edición Especial Special Issue Octubre 2019 DOI: https://doi.org/10.17993/3ctic.2019.83-2.72-89 